\title{
ANALISA HUKUM MENUNDA KEHAMILAN PERKAWINAN USIA DINI PERSPEKTIF ISTIHSAN SEBUAH UPAYA MEMBANGUN KELUARGA BERKUALITAS
}

\author{
Muhamad Dani Somantri, Dahwadin, Faisal \\ Institut Agama Islam Latifah Mubarokiyah (IAILM) Tasikmalaya \\ Sekolah Tinggi Agama Islam (STAI) Al Musaddadiyah Garut \\ Email : muhamaddanisomantri34@gmail.com
}

\begin{abstract}
Abstrak
Perkawinan merupakan ikatan suci antara laki-laki dan perempuan untuk membangun keluarga bahagia, harmonis, sejahtera, unggul, dan berkualitas yang turut berkontribusi dalam mewujudkan program pembangunan keluarga nasional seutuhnya. Namun temuan empirik menunjukan, masih terdapat institusi keluarga yang belum mengoptimalkan tujuan perkawinan. Hal itu disebabkan oleh faktor ketidaksiapan usia perkawinan baik dari aspek fisik, psikis, maupun spiritual. Penelitian ini menerapkan metode pengambilan hukum istihsan terhadap tradisi perkawinan usia dini yang langsung mengalami kehamilan. Jenis Penelitian ini termasuk yuridis kualitatif. Teknik pengumpulan data dilakukan melalui studi kepustakaan dan eksplorasi data primer-sekunder yang kemudian dianalisa. Para ulama berbeda pendapat mengenai hukum menunda kehamilan: mubah, mubah muqayad, makruh, dan haram. Secara normatif praktik menunda kehamilan masih belum sampai pada tahapan hukum yang mewajibkan. Dengan mengkaji data temuan, ternyata praktik kehamilan perkawinan usia dini berimplikasi negatif (madharat) baik bagi dirinya, keluarga, masyarakat, bahkan bangsa. Kehamilan tersebut dapat menghambat pembangunan keluarga berkualitas. Atas dasar analisa metode istihsan dengan mempertimbangkan prinsip almashlahatu al-khas dan al-mashlahatu al-am dan kaidah daf'ul mafaasid muqadamu ala jalbi al-mashaali, maka hukum menunda kehamilan pada perkawinan usia dini adalah wajib.
\end{abstract}

Kata Kunci: Analisa, Hukum, Perkawinan, Istihsan, dan Keluarga.

\begin{abstract}
Marriage is holy bond between boy and girl to build a happy family, harmonious, prosperous, superior, and quality who participated contribute in realize the program full national family development. However findings a empirical shows, still there is a family institution which has not optimized the purpose of marriage. This is caused by factors unpreparedness of marriage age both from physical aspects, psychic, and spiritual. This research applies retrieval method istishan law towards early marriage traditions who immediately experience pregnancy. This type of research includes juridical qualitative. Data collection technique conducted through literature studies and secondary primary data exploration which is then analyzed. The theologian has a different opinion regarding the law of delay pregnancy: mubah, mubah muqayad, makruh, and forbidden. Normatively practice delaying pregnancy still not arrived at the stage obligatory law. By reviewing findings data, evidently practice of pregnancy marriage early age have negative implication (madharat) good for him, family, society, even the nation. The pregnancy can inhibit quality family development. On the basis of istishan method analysis taking into account the principle al-mashlahatu al-khas and almashlahatu al-am and kaidah daf'ul mafaasid muqadamu ala jalbi al-mashaali, then the law delays pregnancy in early marriage is mandatory.
\end{abstract}

Keywords : Analysis, Law, Marriage, Istishan, and Family 


\section{A. Pendahuluan}

Hidup bahagia, sejahtera dan tentram antara pasangan suami dan istri yang terikat dalam satu perkawinan yang sah menjadi dambaan bagi setiap Insan dimuka bumi, manusia pada hakikatnya memerlukan perkawinan guna untuk memenuhi kebutuhan biologis baik dari pihak laki-laki maupun perempuan. Ketentuan terhadap perkawinan sendiri telah diatur di dalam UU No 1 Tahun 1974 pasal 1 sebagaimana telah di sebutkan di atas, hal serupa juga di nyatakan di dalam Kompilasi Hukum Islam di dalam pasal 3 bahwa perkawinan bertujuan untuk mewujudkan kehidupan rumah tangga yang sakinah, mawaddah, dan rahmah. Perkawinan adalah ikatan lahir bathin antara seorang pria dengan seorang wanita sebagai suami isteri dengan tujuan membentuk keluarga (rumah tangga) yang bahagia dan kekal berdasarkan Ketuhanan Yang Maha Esa. Kemudian Kompilasi Hukum Islam menambahkan atau memberikan definisi lain terkait masalah perkawinan bahwasannya sebagaimana terdapat di dalam Pasal 2 adalah akad yang sangat kuat atau mitsaqan ghalidzan untuk mentaati perintah Allah dan melaksanakannya merupakan ibadah. Ijab yang diucapkan oleh seorang mempelai laki-laki yang terikat dalam satu tali perkawinan memiliki beberapa tujuan dalam hidup secara berkelompok dalam satu keluarga ialah hidup bahagia dan kekal atau dalam definisi Kompilasi Hukum Islam (KHI) disebutkan sebagai sakinah, mawaddah dan rahmah, hal ini sesuai dengan ketentuan di dalam al Qur'an Surat Ar Rum ayat 21.

Ketika kalimat akad telah diucapkan oleh seorang calon suami di dalam perkawinan, maka disitu terdapat hak dan kewajiban masing-masing mempelai akan berlangsungnya perkawinan setelah akad di ucapkan oleh seorang laki-laki. Hak dan kewajiban tersebut benar-benar memperhatikan kondisi hubungan rumah tangga, dimana rumah tangga yang menjadi dambaan dan harapan bagi setiap Insan sebagaimana terdapat di dalam UU No. 1 Tahun 1974 untuk memenuhi kebahagiaan kekal berdasakan ketuhanan Yang Maha Esa. Hak dan kewajiban antara seorang suami dan isteri bukan hanya dilihat dari satu sisi mengenai ketentraman hidup di lihat dari agama atau kepercayaan masing-masing mempelai, tetapi juga hak dan kewajiban antara suami dan isteri harus terikat oleh salah satu ketentuan yang dibuat oleh pemerintah guna mewujudkan kehidupan tertib dan damai baik dari pihak laki-laki maupun perempuan.

Pemerintah ikut andil dalam urusan rumah tangga dalam mewujudkan ketentraman di dalamnya, supaya kehidupan warga negara nya hidup dalam suasan damai, aman, tertib, dan tentram, termasuk di dalamnya melakukan inovasi baru dalam hal perkawinan dan perceraian, sebagaimana terdapat di dalam UU No. 1 Tahun 1974 tentang Perkawinan Pasal 2 (1) perkawinan adalah sah, apabila dilakukan menurut hukum masingmasing agamanya dan kepercayaannya itu. (2) tiap-tiap perkawinan di catat menurut peraturan perundang-undangan yang berlaku. Kemudian dalam hal pencatatan perkawinan Kompilasi Hukum Islam (KHI) juga ikut memberikan ketertiban di dalam urusan perkawinan dan perceraian, sebagaimana terdapat di dalam Pasal 5 (1) Agar terjamin ketertiban perkawinan bagi masyarakat Islam setiap perkawinan harus dicatat. (2) Pencatatan perkawinan tersebut pada ayat (1), dilakukan oleh Pegawai Pencatat Nikah sebagaimana yang diatur dalam Undang-undang No. 22 Tahun 1946 Jo 
UU No. 32 Tahun 1954. Menurut konsep al-Quran ${ }^{1}$, tujuan ditasbihkannya syariat perkawinan kepada umat manusia adalah untuk memperoleh ketenangan $(\text { sakinah })^{2}$, rasa cinta $(\text { mawadah })^{3}$, kasih sayang (rahmah $)^{4}$, serta mampu membentuk istitusi keluarga yang ideal. ${ }^{5}$ Perkawinan dipandang sebagai sakralitas amal atas wujud ketundukan seorang hamba kepada Allah SWT (ibadah) untuk kemudian mampu melanjutkan legalisasi estapet keberlangsungan hidup manusia yang secara fitrah senantiasa mengalami pertumbuhan fisik dan perkembangan psikis. UU No. 1 Tahun 1974 Tentang Perkawinan pasal 1 menerangkan bahwa perkawinan merupakan ikatan lahir batin antara seorang pria dan wanita sebagai suami istri dengan tujuan membentuk keluarga (rumah tangga) yang berbahagia dan kekal berdasarkan Ketuhanan Yang Maha Esa. Dalam Instruksi Presiden No. 1 Tahun 1992 Tentang Kompilasi Hukum Islam diuraikan bahwa perkawinan adalah sebuah ikatan yang sangat kuat atau mitsaqan ghalidzan untuk mentaati perintah Allah dan melaksanakannya merupakan ibadah mewujudkan kehidupan rumah tangga yang sakinah, mawadah, dan rahmah.

Sementara UU No. 52 Tahun 2009

${ }^{1}$ QS. Ar-Rum [30]: 21

2 Dalam al-Quran kata sakinah berikut bentuk derivasinya ditulis sebanyak 69 kali yang artinya "menunjukan makna rasa ketentraman, ketenangan jasmani dan rahani". Raghib alAshfahani, al-Mufraadat fi Ghriibi al-Quran, jilid I, (Beirut: Maktabah Nazar Musthafa, t. th), . 236

${ }^{3}$ Dalam al-Quran kata mawadah berikut bentuk derivasinya tercatat sebanyak 25 kali yang berarti "mencintai sesuatu dan berharap agar bisa terlaksana". Raghib al-Ashfahani, al-Mufradat fi...... 615

4 Dalam al-Quran kata rahmah berikut bentuk derivasinya terinci sebanyak 399 kali, artinya "sifat yang mendorong manusia untuk melakukan kebaikan secara suka rela". Raghib al-Ashfahani, al-Mufradat fi....., . 191

${ }^{5}$ QS. Al-Baqarah [2]: 187
Tentang Perkembangan Kependudukan dan Pembangunan Keluarga Bab I Ketentuan Umum Pasal I angka (7) menyebutkan bahwa perkawinan diharapkan akan mempercepat laju pembangunan keluarga nasional, yakni mewujudkan keluarga berkualitas yang hidup dalam lingkungan yang sehat. Keluarga berkualitas adalah keluarga yang dibentuk berdasarkan perkawinan yang sah dan bercirikan sejahtera, sehat, maju, mandiri, memiliki jumlah anak yang ideal, berwawasan ke depan, bertanggungjawab, harmonis, dan bertakwa kepada Tuhan Yang Maha Esa. Pembentukan keluarga berkualitas dalam rangka ikut andil mewujudkan amanat undang-undang tentang perkembangan kependudukan dan pembangunan nasional tidak akan terealisasi secara optimal tanpa adanya integralitas dukungan dari semua komponen yang terlibat langsung dalam internal komunitas keluarga, seperti ayah, ibu, suami, istri, anak, dan anggota keluarga lainnya. Salah satu aspek yang turut mempengaruhi tingkat kualitas keluarga adalah faktor usia pasangan pengantin yang semestinya telah mempunyai kematangan hidup baik mental, sosial, emosional, maupun spiritual.

Data Penelitian Pusat Kajian Gender dan Seksualitas Universitas Indonesia tahun 2015 menemukan angka perkawinan usia dini negara Indonesia menempati peringkat ke-2 teratas di Asia Tenggara yang berakibat putus sekolah, perceraian, ketidakstabilan ekonomi, gangguang kesehatan keluarga, bertambahnya angka kematian ibu (AKI) dan bayi $(\mathrm{ABI})$, serta dampak negatif lainnya. Lebih rinci dijelaskan bahwa 1,60 persen anak perempuan usia 10-17 tahun telah melakukan perkawinan. Dan jika diperhatikan menurut tipe daerah,

6 Koran Harian Kompas, Pernikahan Dini Memicu Masalah, edisi 20 Juni 2015, . 10 
persentase perempuan usia 10-17 tahun yang berstatus kawin di daerah perkotaan yaitu 0,9 persen, sedangka perdesaan hampir tiga kali lipatnya mencapai 2,24 persen. Lebih rinci lagi, dari 1,60 persen anak perempuan usia 10-17 tahun yang berstatus kawin dan cerai di Indonesia, sebesar 35,83 persen kawin di usia 15 tahun ke bawah, 39,45 kawin di usia 16 tahun, 24,72 persen kawin diusia 17 tahun. ${ }^{7}$ Dari sudut pandang kedokteran, tulis M. Ali AsSyabuni, perkawinan usia dini mempunyai dampak negatif baik bagi ibu maupun anak yang dilahirkan. Sedangkan dari aspek sosiologis dapat mengurangi harmonisasi kehidupan berkeluarga yang disebabkan kondisi emosional yang masih labil, gejolak darah muda dan paradigma yang belum matang. Oleh karenanya, praktik pernikahan dini dapat merugikan karena berdampak negatif. ${ }^{8}$ Polemik regulasi batas minimal usia perkawinan bagi perempuan tidak hanya mempermasalahkan pernikahan dini saja, tetapi juga semakin melebar terlebih lagi ketika dikorelasikan dengan munculnya kompleksitas dampak sosial (social problems).

Perkawinan usia dini menyebabkan kehamilan muda yang dekat hubungannya dengan kematian, terganggunya kondisi tubuh karena belum siap melahirkan. Perempuan usia di bawah umur (usia 10-15 tahun) memiliki resiko kematian lima kali lebih besar untuk meninggal dunia dibandingkan perempuan dewasa. Secara umum, kehamilan pertama pada usia dini merupakan faktor penyebab

7 BPS Susenas tahun 2014, Kementerian Pemberdayaan Perempuan dan Perlindungan Anak dan Badan Pusat Statistik, Profil Anak Indonesia 2015, (Jakarta: Kementerian Pemberdayaan Perempuan dan Perlindungan Anak (KPP\&PA), 2015), . 22-23

8 M. Ali Ash-Shabun, Perkawinan Islam, cet. I, (Solo: Mamtaza, 2008), . 120 kamatian perempuan Indonesia pada usia 16 tahun. ${ }^{9}$ Selain itu, perempuan hamil pada usia dini akan menghadapi komplikasi kesehatan ketika persalinan, infeksi, pendarahan hebat, anemia, dan eklampsia. Secara psikologis, perempuan kawin di usia dini akan dibebani tanggung jawab menjadi seorang istri, pasangan seks, dan peran seorang ibu yang seharusnya dilakukan oleh orang dewasa. ${ }^{10}$

Apabila ditelusuri akar permasalahan tingginya tingkat resiko kematian ibu (AKI/mother mortality rate) dan bayi ( $\mathrm{ABI} /$ infrant mortality rate) yang terindikasi dari kondisi jiwa ibu hamil dan janin terganggu, bayi prematur atau cacat, pendarahan yang hebat ketika melahirkan, berat bayi lahir rendah (BBLR), ketidaksiapan mental mengubah peran menjadi sosok orang tua, serta problematika lainnya merupakan dampak yang ditimbulkan oleh pernikahan dini yang paska akad nikah langsung mengalami kehamilan pada paruh tahun pertama dari perkawinan, meraka tidak menunda kekosongan rahim dari pembuahan sperma sampai tibanya masa kematangan secara jasmani, rahani, dan jiwa. Diagram stratifikasi data penyebab kematian perempuan Indonesia paling tinggi disumbangkan oleh faktor terlalu muda dalam kehamilan. Hal ini berkaitan antara usia perempuan saat perkawinan pertama dengan faktor resiko melahirkan. Semakin muda usia perkawinan pertama semakin besar resiko yang dihadapi bagi keselamatan kesehatan ibu maupun bayi, secara mental perempuan muda yang cepat menikah umumnya sangat rentan perceraian karena faktor emosi yang belum stabil, belum memiliki kesiapan

9 Badan Pusat Statistik Susenas tahun 2014, BPS Susenas. Kementrian Pemberdayaan Perempuan..... . 22-23

10 BPS Susenas. Kementrian

Pemberdayaan Perempuan..... . 24 
berumah tangga, serta belum siap menerima pengetahuan tentang kehamilan dan persalinan. ${ }^{19}$

Berdasarkan realita data di atas, terdapat kesenjangan antara kedudukan dan fungsi perkawinan yang seharusnya memberikan kemaslahatan hidup berkeluarga (dasein) dengan keadaan empirik di lapangan (dasollen). Padahal syariat Islam memandang bahwa perkawinan merupakan sarana ibadah yang melahirkan ketenangan hidup, rasa cinta, dan kasih sayang berkeluarga yang pada tahap selanjutnya akan mendapatkan keturunan (hifdzu al-nasl). Demikian juga undang-undang menempatkan perkawinan sebagai langkah awal (starting point) menciptakan keluarga yang sejahtera, maju, mandiri, harmonis, bahagia lahir batin, dan bertakwa kepada Tuhan Yang Maha Esa.

Hemat peneliti, diantara faktor penyebab yang dianggap krusial menimbulkan permasalahan internal keluarga di Indonesia adalah tradisi pasangan perkawinan usia dini yang langsung mengalami kehamilan paska menikah tanpa terlebih dahulu menunggu datangnya kedewasaan fisik dan psikis. Oleh karenanya, dengan menunda kehamilan pada perkawinan usia dini akan mendatangkan kemaslahatan baik bagi individu, keluarga, masyarakat, bangsa dan negara selaras dengan konsep diturunkannya syariat "daf'u al-mafasid muqadamu ala jalbi al-mashalih".

\section{B. Metodologi}

Berdasarkan objek permasalahan yang menjadi fokus kajian, maka metode penelitian yang digunakan adalah yuridis kualitatif, Soerjono Soekanto dan Sri Mumadji menamakan dengan metode penelitian normatif atau metode penelitian hukum kepustakaan ${ }^{11}$. Pendekatan penelitian dilakukan secara deskriptif analitif dengan cara menelaah bahan literatur tentang konsep, prinsip ${ }^{12}$, dan tujuan falsafi hukum Islam. Adapun tujuan dilakukannya penelitian ini adalah untuk menganalisa status hukum syara melalui metode istinbath al-hukmi fi al-istihsan terhadap tradisi perkawinan pada pasangan usia dini yang langsung mengalami masa kehamilan tanpa menundanya terlebih dahulu. Sehingga diharapkan dapat memberikan kejelasan status hukum syar'i terkait praktik penundaan kehamilan bagi pasangan perkawinan muda dalam upaya mewujudkan program pembangunan keluarga berkualitas.

\section{Pembahasan}

\section{Konsep Menunda}

Kehamilan Menurut Islam

Perkawinan hakikatnyan adalah bertemunya dua makhluk lawan jenis yang mempunyai kepentingan dan pandangan hidup yang sejalan, dengan tujuan untuk mewujudkan kehidupan rumah tangga sakinah, mawadah, dan rahmah. Seiring dengan hal tersebut, maka dapat diartikan juga bahwa perkawinan bertujuan untuk membentuk keluarga yang bahagia, kekal dan abadi serta tidak putus begitu saja. Karena pada asasnya bahwa perkawinan adalah merupakan ikatan yang kuat (mitsaqan ghalidzan). Hal ini adalah wajar mengingat perkawinan mempunyai makna yang bermuatan komprehensif, yaitu sosial kemasyarakatan, individu,

11 Soerjono Soekanto dan Sri Mamudji, Penelitian Hukum Normatif (Suatu Tinjauan Singkat), (Jakarta: Rajawali Pers, 2001), hm. 13-14. Lihat pula Jonny Ibrahim, Teori, Metode, dan Panelitian Hukum Normatif, (Malang: Bayumedia Publishng, 2007), . 300

Sedarmayanti dan Syarifudin Hidayat, Metodologi Penelitian, (Bandung: CV Mandar Maju, 2002), .23 
dan agama. Setiap manusia pasti mencita-citakan agar perkawinannya dapat berlangsung kekal abadi selamanya, dan tidak menghendaki terputus ditengah jalan. Tapi adakalanya, suatu perkawinan oleh sebab-sebab tertentu dapat mengakibatkan tidak dapat diteruskan jadi harus diputuskan di tengah jalan atau terpaksa putus dengan sendirinya. Sebab-sebab tersebut sangatlah banyak sepanjang sejarah kehidupan manusia. ${ }^{13}$

Dalam ajaran agama Islam, konsep menunda atau mencegah kehamilan (man'u al-hamli) bukanlah sesuatu yang baru, sebab usaha menunda kehamilan pernah dipraktikan oleh para sahabat semenjak zaman Nabi Muhammad SAW yang dikenal dengan istilah al-azl. Sebagaimana hadits Nabi yang diriwayatkan Bukhari dari Jabbir, "Kami melakukan al-azl pada masa Nabi Muhammmad SAW, sedangkan ayat alQuran masih diturunkan" (HR. Bukhari). Dalam riwayat Muslim dari Jabbir dituliskan bahwa, "Kami pernah melakukan al-a'zl di masa Rasulullah SAW, kemudian berita itu sampai kepadanya, namun Rasulullah tidak melarang kami" (HR. Muslim). ${ }^{14}$ Secara etimologi al-azl berasal dari kata a'zalaya'zilu-a'zlan, artinya memisahkan atau menyingkirkan. ${ }^{15}$ Sedangkan menurut terminologi, al-a'zal didefinisikan sebagai suatu usaha membuang sel sperma di luar rahim ketika merasakan pemancarannya. ${ }^{16}$ Wahbah al-Zuhaili menyederhanakan makna $a$ 'zl dengan

13 Titik Triwulan Tutik, Hukum Perdata dalam Sistem Hukum Nasional, (Kencana Prenada Media Group. 2008). Jakarta. Hal.128.

${ }_{14}$ Muhammad bin Ali bin Muhammad AsySyaukani, Nailul al-Athar, (Beirut: Darl Fikr, t.th), 320

15 Ahmad Warson Munawir, Kamus Munawir Arab-Indonesia Terlengkap, cet.II, (Surabaya: Pustaka Progresif, 2002), . 927

16 Yusuf Qardhawi, Halal dan Haram dalam Islam, terjemahan oleh Ahmad Semait, (Jakarta: Pustaka Nasional, 2010), 323 usaha mengeluarkan sperma di luar vagina. ${ }^{17}$ Dengan demikian $a^{\prime} z l$ upaya suami untuk melepaskan air sperma di luar rahim istrinya agar tidak terjadi pembuahan/konsepsi yang akan berakibat tertundanya masa kehamilan. Aplikasi penerapan $a^{\prime} z l$ dilakukan ketika terjadi hubungan seks. Suami menyengaja menumpahkan sel sperma di luar vagina istri sesaat sebelum suami mengalami ejakulasi (pengeluaran air mani) yang mengakibatkan tertundanya proses penyatuan sel sperma atau konsepsi.

Menurut Thariq al-Thawari, dalam pandangan ajaran Islam perbuatan $a^{\prime} z l$ penundaan kehamilan yang dilakukan oleh mayoritas pasangan perkawinan dilatarbelakangi oleh beberapa faktor, yaitu: pertama, untuk menjaga kondisi kesehatan istri dengan pertimbangan apabila ia mengalami kehamilan, melahirkan atau menyusui akan berbahaya baik bagi dirinya maupun anak yang dikandung. Hal ini dilakukan tentunya berdasarkan atas hasil pertimbangan diagnosa dari tenaga medis atau pihak yang dipercaya. Kedua, dilatarbelakangi oleh paradigma normatif keyakinan beragama, bahwa apabila pasangan perkawinan memiliki anak tanpa berbekal persiapan yang matang, dikhawatirkan tidak akan mampu memberi pendidikan anak yang sesuai dengan tuntutan hukum syara, oleh karenya pasangan tersebut melakukan penundaan kehamilan terlebih dahulu dengan tujuan menghindari dosa agama. Ketiga, mempertimbangkan situasi dan kondisi istri yang sedang berada pada masa menyusui, apabila melakukan hubungan seksual dan kemudian mengalami kehamilan dikhawatirkan akan membahayakan anak yang sedang membutuhkan pasokan air susu ibu

17 Wahbah al-Zuhaili, Fikih al-Islami wa adillatuhu, terjemahan Abdul Hayyie al-Kattani, dkk, (Jakarta: Gema Insani, 2011), Jld., IX, . 104 
(ASI). Keempat, tidak menginginkan hamba sahaya perempaun memiliki anak keturunan dari hasil darah daging majikannya. Kelima, keadaan darurat berkaitan dengan kondisi fisik istri yang lemah, ditakutkan apabila hamil akan mengakibatkan terganggunya kesehatan istri atau bahkan mendatangkan kematian. Keenam, kondisi kesuburan (ovulasi) yang dialami oleh istri sehingga dituntut untuk melakukan $a$ 'zl guna menunda masa kehamilan sementara waktu. ${ }^{18}$

\section{Status Hukum Menunda Kehamilan di Kalangan Ulama}

Secara umum, para ulama berbeda pendapat dalam hal menyikapi hukum $a$ 'zl yang dipandang sebagai solusi alternatif bagi pasangan perkawinan untuk menunda masa kehamilan atau menagguhkan keinginan memiliki anak keturunan. Berikut ini beberapa status hukum syar'i tentang menunda masa kehamilan.

\subsection{Mubah Mutlak}

Terminologi mubah mutlak adalah boleh memilih salah satu diantara melaksanakan atau meninggalkan tanpa adanya alasan tertentu (mutlak), sebab syara telah memberikan izin untuk melaksanakan ataupun sebaliknya meninggalkan sama sekali. Kelompok ulama ini telah menjadikan status hukum $a$ 'zl sebagai solusi menunda kehamilan dengan mubah mutlak, maksudnya syara memberikan kebebasan memilih bagi pasangan perkawinan untuk melakukan $a$ 'zl dalam rangka menunda kehamilan ataupun tidak melakukan $a^{\prime} z l$, mengusahakan kehamilan agar memiliki anak keturunan meskipun tanpa adanya alasan tertentu. Pendapat yang membolehkan $a$ 'zl secara mutlak

18 Thariq al-Thawari, KB Secara Islam, (Solo: PT. Aqwam Media Profetik, 2007), . 16-17 dipegang oleh mayoritas ulama madzhab Syafi'iyah termasuk imam Ghazali dengan berlandaskan pada hadits yang diriwayatkan oleh Jabir r.a., "Kami pernah melakukan perbuatan a'zl pada masa Rasulullah SAW ketika al-Quran diturunkan, seandainya apabila perbuatan kami itu dilarang, niscaya ada sebagian ayat al-Quran yang melarang perbuatan kami itu" (HR. Mutafaq a'laih).

Menurut al-Ghazali, tidak ada nash yang mengqiyaskan hukum keharaman $a$ 'zl, sebab hukum asal yang digunakan untuk menentukan kejelasan status hukum $a^{\prime} z l$ adalah menyamakannya dengan hukum meninggalkan nikah atau menghindari hubungan seksual setelah perkawinan. Perbuatan tersebut (nikah, menghindari bersetubuh, $a$ 'zl dan mempunyai anak) merupakan tahapan yang tidak bisa dipisahkan. Apabila praktik $a$ 'zl dilarang/diharamkan, maka perbuatan sejenisnyapun pasti diharamkan. A'zl tidak dapat dikategorikan sebagai perbuatan yang identik dengan aborsi sebagai kejahatan terselubung (wa'du al-khafi), karena aborsi termasuk sebuah bentuk kejahatan yang dilakukan setelah adanya anak, sehingga aborsi digolongkan sebagai perbuatan dengan tingkat kejahatan yang paling keji. Mengenai lahirnya seorang anak, ungkap al-Ghazali, tidak saja karena menyatunya sel sperma dengan sel ovum dalam rahim wanita, tetapi juga merupakan hasil perbuatan Tuhan (taqdir) Yang Maha Kuasa. Keberadaan konsepsi sel sperma dalam rahim hanya bagian prasyarat lahiriah proses terciptanya anak.

Apabila ada pendapat yang mengharamkan atau memakruhkan perbuatan $a^{\prime} z l$, maka lebih tepatnya hukum tersebut disandarkan pada niat yang menjadi motif perbuatan $a^{\prime} z l$. Sebab, tidak sedikit dari pasangan 
perkawinan yang melakukan $a^{\prime} z l$ sebagai metode menunda kehamilan dilatarbelakangi dengan niat keliru. Diantara niat yang mendasari perbuatan $a$ 'zl adalah pihak majikan yang merasa takut apabila hamba sahayanya merdeka setelah melahirkan, menjaga kondisi istri agar selalu terlihat cantik dikarenakan belum punya anak, ketakukan tidak dapat menunaikan nafkah apabila punya banyak anak, kekhawatiran melahirkan anak perempuan yang dianggap membawa kehinaan bagi keluarga (tradisi jahiliyah), menjaga penampilan diri agar selalu terlihat menarik. ${ }^{19}$

\section{2. $\quad$ Mubah Muqayad}

Mubah muqayad adalah ketetapan hukum syara yang memperbolehkan untuk mengerjakan suatu perbuatan dengan persyaratan tertentu atau meninggalkannya sama sekali. Ulama lain memberikan hukum mubah muqayad terhadap penundaan kehamilan pada perkawinan, artinya menunda kehamilan pada perkawinan hukumnya diperbolehkan tetapi harus memenuhi persyaratan tertentu, apabila belum sampai memenuhi persyaratan, lebih baik dijauhi, khawatir akan mendekati hukum makruh tahrim (makruh dekat degan keharaman) atau boleh pula meninggalkannya, perkawinan yang langsung mengusahakan kehamilan. Bentuk pemenuhan persyaratan yang dimaksud adalah atas dasar adanya keridhaan/kerelaan dari pihak istri. Status hukum mubah muqayad terhadap $a$ 'zl sebagai metode penundaan kehamilan pada perkawinan diperkuat oleh mayoritas kalangan ulama Hanabilah yang berpegang pada landasan hukum dari hadits dalam riwayat Umar Ibn Khattab, "Rasulullah $S A W$ pernah melarang perbuatann a'zl

${ }^{19}$ Abu Malik Kamal, FIkih Sunah Wanita, (Jakarta: Pena Pundi Aksara, 2007), . 65-66 apabila tanpa didasari izin dari pihak istrinya" (HR. Ibn Majah). Hukum syara melarang praktik $a^{\prime} z l$ tanpa sepengetahuan atau izin dari pihak istri, sebab faktor kerelaan pihak istri menjadi salah satu syarat kebolehan $a^{\prime} z l$, hal itu dilakukan berdasarkan analisis yang berkaitan dengan permaslahan akad (ikatan) perkawinan, pemenuhan hak dan tanggung jawab suami istri, dan kebolehan memiliki anak keturunan.

Pertama, alasan yang berkaitan dengan unsur akad/ikatan, perkawinan merupakan sebuah ikatan suci antara laki-laki dan perempuan untuk memperoleh bangunan rumah tangga harmonis didasari ketakwaan kepada Tuhan Yang Maha Esa. Memelihara ikatan/akad perkawinan berupa timbulnya rasa kerelaan merupakan wujud nyata yang dilakukan pasangan suami istri untuk menunaikan kewajiban. Teori akad menyebutkan bahwa indikator keabsahan akad/ikatan terukur dengan adanya asas kerelaan hati (prinsip al-ridhaiyah) dari kedua belah pihak yang berakad (al-a'qidaini). Sebagaimana kaidah fikih, labuda min al-taraadhiy fi jami'i uquudi ilmu'awadhati wa uquudi al-ta'baru'ati, artinya "diharuskan adanya saling kerelaan dalam setiap akad, baik yang sifatnya bisnis ataupun sumbangan karena Allah semata."

Salah satu usaha memelihara akad perkawinan dapat dilakukan melalui permintaan izin lebih terlebih dahulu dari suami kepada istri ketika akan melakukan a'zl dalam hubungan seksual. Apabila $a$ 'zl dilakukan tanpa sepengetahuan pihak istri atau keridhaanya, maka hukum syara mengaharamkan. Sebab unsur pemaksaan akan menggurkan keridhaan, sesuai kaidah fikih al-ikrahu yasquthu al-ridha. Kedua, alasan yang berhubungan dengan unsur hak dan kewajiban, setelah dilangsungkannya 
akad perkawinan, maka seketika itu pula antara laki-laki dan perempuan berubah status menjadi pasangan suami istri yang berdampak lahirnya tanggung jawab baru berkaitan dengan pemenuhan hak dan kewajiban rumah tangga. Kewajiban suami merupakan rangkaian hak istri yang harus terpenuhi, sedangkan kewajiban istri sama dengan hak suami yang harus dijalankan. Diantara hak istri yang menjadi kewajiban suami untuk direalisasikan adalah memberikan nafkah secara menyeluruh lahir dan batin, seperti memberikan kepuasan kepuasan terhadap istri dalam berhubungan seksual sebagai nafkah batin suami yang menjadi hak istri. Ketika perbuatan $a$ 'zl dilakukan dalam hubungan seksual antar pasangan perkawinan, secara tidak langsung suami telah melanggar sebagian kewajibannya secara sengaja. Dengan kata lain, pihak istri terhalang dari haknya, oleh karena itu, syara mewajibkan bagi suami untuk meminta maaf atau memohon izin terlebih dahulu kepada istri pada saat akan melakukan praktik $a$ 'zl dalam hubungan seksual. Tujuannya agar istri tidak merasa keberatan (ridha) apabila sebagian dari haknya yakni mendapakan kepuasan nafkah batin dari suami tidak dipenuhi.

Ketiga, alasan yang berkaitan pola pandang kedudukan anak keturunan, salah satu tujuan dianjurkannya perkawinan adalah untuk memperoleh anak keturunan dari perjalanan ikatan yang sah dan suci. Keberadaan keturunan bagi keluarga berfungsi sebagai fasilitas guna mengabadikan ikatan keluarga melalui kiprah generasi penerus. Sebab, ketercapaian tujuan perkawinan ditandai dengan kehadiran anak keturunan. Perkawinan yang langsung dikaruniai anak menunjukan rumah tangga yang berhasil, bahkan dijadikan sebuah kebahagiaan. Sebaliknya perkawinan yang belum dianugrahi anak, dianggap belum merasakan kesempurnaan berumah tangga, tidak sedikit dari pasangan suami istri yang mengharapkan anak dalam waktu yang relatif lama.

Dengan demikian, apabila pasangan perkawinan akan melakukan $a$ 'zl guna menunda lahirnya anak, maka suami wajib mempertanyakan keridhaan dari pihak pasangannya (istri) karena hal itu merupakan representasi persetujuan kebolehan yang dibuktikan berupa izin yang diikrarkan oleh istri.

\subsection{Makruh}

Makruh adalah ketetapan hukum syara terhadap suatu perbuatan mukalaf yang apabila dilaksanakan tidak akan mendapat pahala kebaikan, sebaliknya apabila ditinggalkan tidak akan memperoleh dosa, namun hukum lebih baik dihindari karena terdapat hikmah keutamaan di dalamnya. Hukum $a$ 'zl yang lainnya sebagai metode penundaan kahamilan adalah makruh, maksudnya Islam menganjurkan kepada pasangan suami istri agar meninggalkan perbuatan $a$ 'zl dari pada melakukannya. Praktik $a$ 'zl lebih baik dihindari dengan catatan tidak ada motif (illat) yang termasuk ke dalam kategori darurat syara, seperti pertimbangan aspek kesehatan bagi istri atau anak, sedang menyelesaikan pendidikan ilmu agama, kekhawatiran tidak dapat memberikan pendidikan yang terbaik bagi anak dikarenakan kesiapan yang belum matang. Kelompok ulama yang memakruhkan hukum a'zl sebagai sebuah metode menunda kahamilan didukung oleh kalangan ulama Malikiyah dan Hanafiyah yang merujuk pada hadits Nabi SAW dalam riwayat Anas Ibn Malik: "Dahulu Rasulullah SAW selalu memerintah kami untuk menikah dan beliau sangat melarang kami untuk membujang (tidak mau menikah untuk selama-lamanya). Kemudian beliau 
bersabda: Nikahilah oleh kalian wanita yang penuh kasih sayang dan subur. Karena sesungguhnya pada hari kiamat kelak, aku akan berbangga di hadapan para nabi dengan jumlah kalian yang banyak" (HR. Abu Dawud)

Kandungan redaksi hadits di atas menganjurkan kepada umat Islam, agar melangsungkan perkawinan (jangan membujang) dengan perempuan yang disayangi dan memiliki kondisi kesuburan rahim (ovulasi) sebab dengan kasih sayang dan kesuburan istri, perkawinan akan menghasilkan banyak anak keturunan. Secara eksplisit praktik $a$ 'zl sebagai metode penunda masa kehamilan sangat bertentangan dengan isi hadits yang menganjurkan banyak anak. Dengan adanya $a^{\prime} z l$ kehamilan istri menjadi tertunda yang berakibat jumlah anak terbatas. Sehingga tujuan perkawinan yaitu untuk memperbanyak keturunan umat nabi Muhammad SAW tidak tercapai. Oleh karenanya, menurut madzhab Hanafi dan Maliki praktik menunda masa hamil untuk punya anak keturunan dengan metode $a^{\prime} z l$ hukumnya adalah makruh. Untuk meraih kemaslahatan, Islam memerintahkan agar $a^{\prime} z l$ dalam perkawinan ditinggalkan daripada dilaksanakan.

\subsection{Haram Mutlak}

Haram mutlak adalah ketetapan hukum syara yang dibebankan kepada orang mukalaf terhadap suatu perbuatan hukum yang apabila dilaksanakan akan mendapat kemadaratan, sebaliknya jika ditinggalkan akan memperoleh kebaikan tanpa alasan apapun. Status hukum $a$ 'zl sebagai metode penundaan kehamilan adalah haram mutlak, maksudnya status hukum yang disandarkan pada metode $a^{\prime} z l$ bagi pasangan perkawinan yang jika dilakukan akan memperoleh kemadaratan, namun apabila dijauhi akan mendatangkan kemasalahatan.
Pendapat yang mengharamkan secara mutlak praktik $a$ 'zl digagas oleh kalangan ulama tekstualitas madzhab Dhawahiriyah, salah satunya Ibnu Hazm al-Andalusia yang berpegang pada dasar hukum hadits Rasulullah SAW: "Dari Aisyah, dari Judamah binti Wahab, saudara perempuan bangsa Akaasyah berkata: Aku hadir ketika Rasulullah SAW yang berada di tengah-tengah orang, kemudian beliau bersadba: Sesungguhnya semula akau melarang (kalian) dari perbuatan gillah. Lalu aku melihat bangsa Romawi dan Persia dimana mereka melakukan gillah terhadap anak-anak mereka. ternyata hal itu tidak membahayakan anak-anak mereka". Kemudian para shahabat bertanya kepada beliau tentang 'azl. Maka Rasulullah SAW bersabda : "Itu adalah pembunuhan tersembunyi" (HR. Muslim)

Ibnu Hazm mengaharmkan a'zl secara mutlak, baik perempuan merdeka mupun hamba sahaya. Beliau merujuk pada hadits dalam riwayat Aisyah yang dianggapnya sebagai hadits shahih. Pada mulanya memang $a^{\prime} z l$ diharamkan karena mengingat semua status hukum perbuatan diperbolehkan selama belum ada dalil yang menunjukan keharaman. Hadits dari Aisyah itu menghapus (nasikh) hadits yang menghalalkan $a$ 'zl, sebab secara tidak langsung perbuatan tersebut dianggap sebagai bentuk usaha pembunuhan bayi dengan cara terselubung (wa'dul al-khafi). Pendapat Ibnu Hazm yang mengharamkan $a^{\prime} z l$ mendapat komentar dari kalangan ulama, diantaranya Ibnu Hajar yang menyatakan bahwa: (1) hadits Judaman yang diterima dari Aisyah bertentangan dengan hadits yang jumlah perawinya lebih banyak. Makna kandungan hadits tersebut bertolaKBelakang dengan redaksi dua hadits yang diriwayatkan oleh Jabir dan Abu Hurairah yang membolehkan a'zl; (2) walaupun praktik $a$ 'zl dianalogikan seperti 
mengubur bayi yang masih hidup, namun tidak serta merta status hukumnya menjadi haram; (3) antara hadits Judamah dan hadits yang menyebutkan pengingkaran Nabi SAW terhadap tradisi kaum Yahudi dapat disamakan maksud dan tujuannya dengan hukum makruh tanzih, karena $a$ 'zl dikhususkan agar wanita tidak mengalami masa hamil; dan (4) praktik $a$ 'zl tidak boleh dimaknai sebagai usaha penguburan bayi, sebelum sel sperma mengalami konsepsi dalam rahim istri. ${ }^{20}$

Meskipun demikian, memang secara teknis tak dapat dipungkiri bahwa praktik $a^{\prime} z l$ bisa juga menjadi haram, terlarang dalam ajaran Islam apabila keberadaannya merusak harmonisasi hubungan rumah tangga sebagai tujuan perkawinan. Kerukunan berumah tangga diantaranya berkaitan dengan naluri syahwat untuk mencapai orgasme ketika melakukan hubungan seksual.

\section{Konsep Menunda Kehamilan Menurut Undang-Undang}

Menunda kehamilan adalah serangkaian usaha yang dilakukan secara sengaja oleh pasangan perkawinan dalam rangka menghalangi terjadinya proses penyatuan sel sperma dengan sel telur (konsepsi) dalam rahim yang mengakibatkan tertundanya masa kehamilan istri mempunyai anak keturunan. Pada tahapan teknisnya, tata cara menunda kehamilan bagi pasangan perkawinan memiliki ungkapan kebahasaan yang berlainan, tergantung sudut pandang dari jenis disiplin ilmu yang melarbelakanginya. Ajaran Islam menyebut metode atau alat pencegahan kehamilan dengan istilah $a^{\prime} z l$, regulasi peraturan perundang-undangan yang berlaku di Indonesia sering menuliskannya dengan istilah kontrasepsi atau pengaturan kehamilan. ${ }^{21}$ Sedangkan bentuk institusi resmi yang bertujuan melakukan perencanaan pendampingan, memberi pembekalan, dan memandu penggunaan alat kontrasepsi disebut dengan istilah $\mathrm{KB}$, kepanjangan dari keluarga berencana.

Menurut Suratun, etimologi kontrasepsi berasal dari dua akar kata, yakni kontra dan konsepsi. Kontra artinya melawan atau mencegah, sementara konsepsi mengandung makna pembuahan, penyatuan, atau pertemuan antara sel telur dengan sel sperma yang akan mengakibatkan kehamilan. ${ }^{23}$ Kamus Besar Bahasa Indonesia mendefinisikan kontrasepsi sebagai cara untuk mencegah kehamilan menggunakan alat atau obat pencegah kehamilan, seperti spiral, kondom, atau pil anti hamil. ${ }^{24}$

Jadi pengertian kontrasepsi adalah suatu usaha untuk melawan, mencegah, atau menghindari terjadinya kehamilan dengan menggunakan alat medis tertentu agar tidak terjadi penyatuan sel sperma dan sel telur ketika melakukan hubungan seksual. Kontrasepsi sebagai metode pencegah kehamilan yang memiliki beberapa karakteristik, diantaranya dilakukan dengan menggunakan alat atau obat, dampaknya bersifat sementara atau permanen, mengusahakan agar tidak terjadi ovulasi atau kesuburan, melumpuhkan sel sperma, dan menghalangi pertemuan sel

${ }^{21}$ Undang-Undang Nomor 52 Tahun 2009 Tentang Perkembangan Kependudukan dan Pembangunan Keluarga Bab I Ketentuan Umum Pasal 1 poin 8

https://id.wikipedia.org/wiki/Pengaturan_kelahiran\# Efek. Diakses pada hari Sabtu tanggal 28 Juli 2018 pukul 08.50 WIB

23 Suratun (at all), Pelayanan Keluarga Berencana dan Pelayanan Kontrasepsi, (Jakarta: Trans Info Media, 2008), . 7

24 Pusat Bahasa, Kamus Besar Bahasa Indonesia, cet. IV, (Jakarta: PT. Gramedia Pustaka Utama, 2011), . 730 
sperma, sehingga efektivitas keberhasilan kontrasepsi hampir mencapai $100 \%$ dalam usaha menunda kehamilan pasangan perkawinan.

\section{Tujuan Program Keluarga Berencana}

Untuk meresmikan kedudukan kontrasepsi sebagai metode pengatur kelahiran anak yang akan berkontribusi dalam upaya mewujudkan pembangunan keluarga nasional yang berkualitas sekaligus menekan mobilisasi jumlah penduduk, maka pemerintah telah mengaturnya melalui program pencanangan keluarga berencana. ${ }^{25}$ Makna keluarga berencana adalah upaya mengatur kelahiran anak, jarak dan usia ideal kelahiran, melalui promosi, perlindungan, dan bantuan sesuai dengan hak reproduksi untuk mewujudkan keluarga yang berkualitas. $^{26} \quad$ Karena melalui pengaturan kelahiran anak diharapkan dapat membantu pasangan suami istri agar melahirkan pada usia yang ideal, memiliki cukup jumlah anak, dan mengatur jarak kelahiran anak dengan menggunakan cara, alat, dan obat kontrasepsi. $^{27}$

Selain itu, penerapan program keluarga berencana, alat kontasepsi secara tidak langsung telah merealisasikan perlindungan terhadap

${ }^{25}$ Undang-Undang Nomor 52 Tahun 2009

Tetang Perkembangan Kependudukan dan Pembangunan Keluarga Bab Ketentuan Umum Pasal 20

${ }^{26}$ Undang-Undang Nomor 52 Tahun 2009

Tetang Perkembangan Kependudukan dan Pembangunan Keluarga Bab Ketentuan Umum Pasal 1 poin 8. Pengertian keluarga berencana yang sama dinyatakan pula dalam Peraturan Pemerintah Nomor 87 Tahun 2014 Tentang Perkembangan Kependudukan, keluarga berencana, dan sistem Informasi Keluarga Bab I Ketentuan Umum

27 Undang-Undang Nomor 52 Tahun 2009

Tetang Perkembangan Kependudukan dan Pembangunan Keluarga Bab Ketentuan Umum Pasal 1 point 9 hak kesehatan reproduksi manusia yang mencakup: (1) promisi dan konseling kelangsungan hidup ibu, bayi, dan anak (KHIBA); (2) pencegahan penyakit menular seksual seperti HIV (Human Immunodeficiency Virus), dan AIDS (Acquired Immune Deficiency Syndrome); (3) pencegahan penyakit kanker alat reproduksi (KAR); (4) pencegahan dan penanganan alat infertilitas; dan (5) kesehatan alat reproduksi remaja (KRR). ${ }^{28}$ Khusus point (5), unsur kesehatan reproduksi remaja menjadi bagian integral yang tak terpisahkan dari keutuhan kesehatan remaja sesuai amanat Undang-Undang Nomor 36 Tahun 2009 Tentang Kesehatan Pasal 136 ayat (1) upaya pemeliharaan kesehatan remaja harus ditunjukan untuk mempersiapkan menjadi orang dewasa yang sehat dan produktif, baik sosial maupun ekonomi; ayat (2) upaya pemeliharaan kesehatan remaja sebagaimana yang dimaksud pada ayat (1) termasuk alat reproduksi remaja dilakukan agar terbebas dari berbagai gangguan kesehatan yang dapat menghambat kemampuan menjalani kehidupan reproduksi yang sehat. $^{29}$

Peraturan Pemerintah Nomor 87 Tahun 2014 Tentang Perkembangan Kependudukan dan Pembangunan Keluarga, Keluarga Berencana, dan Sistem Informasi Keluarga menjelaskan lebih lebar tentang tujuan diselenggarakannya program keluarga berencana adalah, pertama, mengatur kehamilan yang diinginkan. Kedua, menjaga kesehatan dan menurunkan angka kematian ibu, bayi, dan anak.

${ }^{28}$ Surya Chandra Surapaty (at. all), Buku Kebijakan Program Kependudukan, Keluarga Berencana, dan Pembangunan Keluarga dalam Mendukung Keluarga Sehat, (Jakarta: BKKBN, 2016), . 46

${ }^{29}$ Undang-Undang Nomor 36 Tahun 2009 Tentang Kesehatan. Lihat juga Peraturan Pemerintah Nomor 61 Tahun 2014 Tentang Kesehatan Reproduksi 
Ketiga, meningkatkan akses dan kualitas informasi, pendidikan, konseling, dan pelayanan keluarga berencana, dan kesehatan reproduksi. Keempat, meningkatkan partisipasi dan kesertaan pria dalam praktik keluarga berencana. Dan kelima, mempromosikan penyusuan bayi sebagai upaya menjarangkan jarak kehamilan. ${ }^{30}$

Sarwono dalam bukunya merinci prioritas program keluarga berencana yaitu (1) pemberdayaan masyarakat untuk membangun keluarga kecil berkualitas; (2) menggalang kemitraan dalam peningkatan kesejahteraan, kemandirian, dan ketahanan keluarga; (3) meningkatkan kualitas pelayanan keluarga berencana dan kesehatan reproduksi; (4) meningkatkan promosi, perlindungan dalam upaya nyata mewujudkan hak reproduksi; (5) meningkatkan upaya pemberdayaan perempuan untuk mewujudkan kesetaraan dan keadilan gender melalui program keluarga berencana; dan (6) mempersiapkan sumber daya manusia yang unggul dan berkualitas sejak pembuahan dalam kandungan sampai dengan lanjut usia. ${ }^{31}$ Berdasarkan uraian tersebut dapat diketahui bahwa tujuan pokok program keluarga berencana ialah membentuk keluarga yang unggul, berkualitas, sehat, dan mandiri. Sebab, widharna berpandangan bahwa substansi tugas utama keluarga adalah sebagai sarana dalam memenuhi kebutuhan jasmani, rohani, dan sosial anggota yang mencakup pemeliharaan, perawatan anak keturunan, bimbingan perkembangan kepribadian serta kepentingan sikap spiritual internal

\footnotetext{
${ }^{30}$ Peraturan Pemerintah Nomor 87 Tahun 2014 Tentang Perkembangan Kependudukan, Keluarga Berencana, dan Sistem Informasi Keluarga bagian kesatu Umum Pasal 18, . 12-13

31 Prawirihardjo Sarwono, Faktor yang Mempengaruhi Perkembangan KB, (Jakarta: Yayasan Bina Pusataka, 2005), . 1
}

keluarga. ${ }^{32}$

Anggota keluarga terutama pasangan suami istri yang masih berusia subur merupakan akseptor penting yang dianjurkan mengikuti kebijakan program keluarga berencana agar mendapat keturunan ideal dengan keteraturan jumlah anak. lebih jauh, tujuan akseptor mengikuti program keluarga berencana yang ditawarkan pemerintah diharapkan dapat menerima rangkaian program positif wujud konkret membangun keluarga nasional seutuhnya. Sebaliknya, apabila institusi keluarga yang dianggap masih layak menjadi akseptor namun tidak mengikuti program keluarga berencana, dikhawatirkan akan menimbulkan problematika berkaitan dengan permasalahan ketidakseimbangan antara reproduksi keturunan yang tak terkontrol dengan minimnya kematangan aspek ekonomi atau tingkat pendidikan yang akhirnya berdampak negatif terhadap perkembangan sumber daya manusia. Fenomena demikian secara tidak langsung tentunya akan menghambat cita-cita negara Indonesia dalam hal mempercepat laju program pemerintah membangun keluarga nasional seutuhnya sebagaimana amanat yang disampaikan oleh Pembukaan Undang-Undang Dasar 1945 berkaitan pembangunan bangsa.

\section{Analisa Hukum Islam}

Istihsan merupakan suatu metode ushul fikih yang digunakan dalam penggalian ketetapan hukum Islam (istinbath al-hukmi) dengan cara memindahkan status suatu hukum perbuatan/benda yang telah ditetapkan melalui keabsahan syara kepada hukum baru yang dianggap lebih baik untuk diterapkan atau ditinggalkan

32 Indra Wirdhana, Delapan Fungsi Keluarga, (Jakarta: Direktorat Bina Ketahanan Remaja, 2013), . 2 
berdasarkan adanya indikator tingkat kemaslahatan atau kesulitan. Jenis istihsan yang diaplikasikan terhadap penggalian hukum praktik penundaan kehamilan pada perkawinan usia muda dalam mewujudkan institusi keluarga yang berkualitas adalah istihsan bi almashlahati, artinya mencari model hukum yang lebih baik dengan alasan (i'llat) prioritas pertimbangan kemaslahatan.

Hukum asal dari praktik menunda kehamilan adalah mubah atau boleh berdasarkan pada metode qiyas/analog yang menyamakan antara perbuatan menunda kehamilan dengan kegiatan bermuamalah sesuai kaidah fikih alashlu fi al-mu'amalah al ibahah hatta an yadulla dalilun a'la tahrimiha. Maksudnya perbuatan menunda kehamilan boleh dilakukan ataupun boleh pula ditinggalkan dan tidak akan mengakibatkan adanya sanksi hukum syara baik dalam bentuk pahala maupun dosa.

Sementara apabila merujuk pada hasil penelitian ilmiah tentang fenomena sosial kehamilan pada perkawinan usia di bawah umur berikut ragam problematiknya, maka akan ditemukan data empirik terkait dampak negatif (mafsadah) yang ditimbulkan oleh praktik kehamilan pada perkwinan usia di bawah umur baik bagi individu, keluarga, lingkungan sosial, dan masyarakat. Terlebih lagi ketika dikorelasikan keberadaanya dengan program pemerintah mewujudkan pembangunan keluarga nasional seutuhnya.

Berdasarkan atas hasil kajian penelitian ilmiah para ilmuan di lapangan, ada beberapa permasalahan argumen hukum (i'llat) akibat praktik kehamilan pada perkawinan di bawah umur, diantaranya: (1) menyebabkan tingginya tingkat resiko kematian Ibu dan Bayi terutama pada masa hamil atau persalinan akibat perebutan kebutuhan asupan gizi yang tidak seimbang antara ibu yang mengandung dengan janin; (2) gangguan kesehatan fisik, psikis, dan emosional yang dialami oleh calon ibu akibat ketidaksiapannya untuk berubah peran menjadi orang tua; (3) minimnya pengetahuan dan pengalaman dalam mengurus kehidupan rumah tangga, sehingga apabila menghadapi permasalahan keluarga sering dihadapi dengan pertengkaran dan jarang berakhir pada perceraian; (4) tradisi putus sekolah, berhenti mengenyam pendidikan formal (drop out), terutama bagi kalangan yang dikategorikan pemerintah sebagai usia wajib menempuh pendidikan dua belas tahun (wajardiknas).

Dan masih banyak dampak negatif lainnya yang ditimbulkan oleh praktik kehamilan pada perkawinan usia di bawah umur, baik dalam bidang kesehatan keluarga, hak kesehatan reproduksi wanita, kesehatan jasmani dan rohani, ketahanan ekonomi, tingkat pendidikan, dan sosial kemasyarakatan yang semuanya secara tidak langsung akan menjadi hambatan dalam mewujudkan cita-cita membangun bangsa seutuhnya.

Berdasarkan fakta objektif di atas, maka istihsan berpandangan bahwa terkait implikasi negatif dari hasil praktik kehamilan pada perkawinan di bawah umur, harus dicegah, ditolak, atau dihindari melalui solusi alternatif yakni prorgam keluarga berancana (KB) dengan cara menggunakan alat, obat, metode kontrasepsi yang bertujuan untuk menunda masa kehamilan pada perkawinan di bawah umur, sebagaimana kaidah fikih menegaskan daf'ul mafasid muqadamu a'la jalmi almashalih (mencegah kemadaratan harus diprioritaskan dari pada mendatangkan kemaslahatan). 
Alhasil, hukum asal menunda kehamilan adalah diperbolehkan (alibahah), namun apabila tradisi kehamilan pada perkawinan usia di bawah umur dapat mengakibatkan timbulkan problematika kemadaratan yang bertolakbelakang dengan tujuan falsafah hukum Islam (i'llat bi almaslahat), maka menurut istihsan perbuatan tersebut wajib hukumnya ditinggalkan melalui solusi alternatif mengikuti program penundaan kehamilan terutama pada pasangan perkawinan usia di bawah umur. Secara sederhana analisa hukum dengan menggunakan metode istihsan dapat dilihat pada bagan berikut:

Bagan Analisa Hukum:

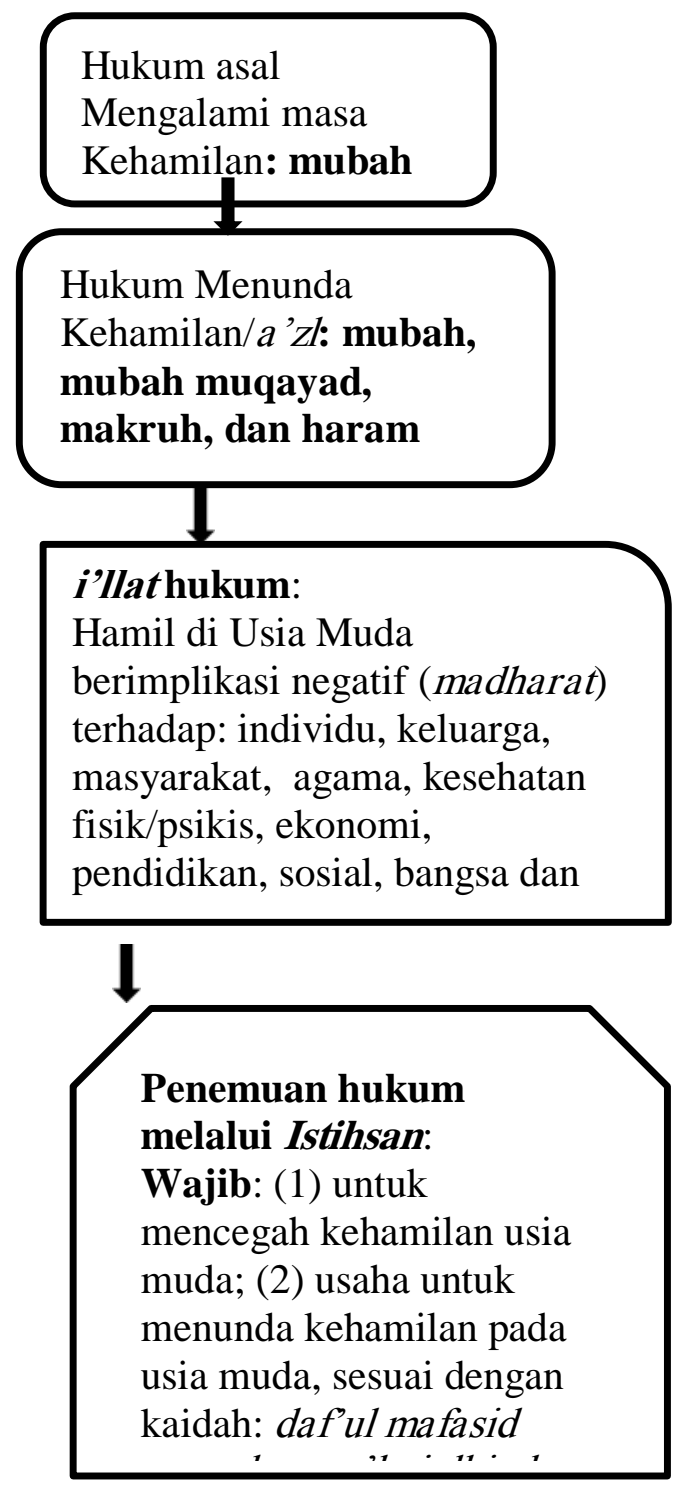

\section{Kesimpulan}

Dari uraian di atas, dapat ditemukan beberapa catatan penting:

a. Menurut ajaran Islam, hukum memiliki anak keturunan adalah mubah/diperbolehkan. Para ulama berbeda pendapat mengenai hukum menunda kehamilan bagi pasangan suami istri, yaitu: mubah, mubah mutlak, makruh, dan haram. Jadi secara normatif praktik menunda kehamilan belum sampai pada tahapan hukum yang bersifat mewajibkan.

b. Merujuk pada temuan empirik data penelitian tentang praktik kehamilan, terutama yang dialami oleh pasangan perkawinan di bawah umur ternyata berimplikasi negatif (madharat) baik bagi dirinya, keluarga, masyarakat, bangsa bahkan negara. Secara tidak langsung kehamilan pada perkawinan usia dini telah menghambat pembangunan keluarga seutuhnya. Oleh karena itu, berdasarkan analisa metode istihsan dengan pertimbangan adanya prinsip al-mashlahat al-khas dan almashlahatu al-am dan kaidah daf'ul mafaasid muqadamu ala jalbi almashaalih, untuk mewujudkan keluarga berkualitas, maka hukum menunda kehamilan pada perkawinan di bawah umur adalah wajib syar'i.

\section{E. Daftar Pustaka}

al-Ashfahani, Raghib. t.th. al-Mufraadat $f i$ Ghriibi al-Quran. Jilid I. Beirut: Maktabah Nazar Musthafa.

al-Thawari, Thariq. 2007. KB Secara Islam. Solo: PT. Aqwam Media Profetik.

al-Zuhaili, Wahbah. 2011. Fikih al-Islami wa Adillatuhu, Terjemahan Abdul Hayyie al-Kattani, dkk. 
Jakarta: Gema Insani.

Ash-Shabun, M. Ali . 2008. Perkawinan Islam. cet. I. Solo: Mamtaza.

Asy-Syaukhani, Muhammad bin Ali bin Muhammad. t.th. Nailul alAthar. Beirut: Darl Fikr.

https://id.wikipedia.org/wiki/Pengaturan_k elahiran\#Efek. Diakses pada hari Sabtu tanggal 25 Juli 2018 pukul $20.50 \mathrm{WIB}$

Ibrahim, Jonny. 2007. Teori, Metode, dan Panelitian Hukum Normatif. Malang: Bayumedia Publishng.

Kementerian Pemberdayaan Perempuan dan Perlindungan Anak dan Badan Pusat Statistik. 2015. Profil Anak Indonesia. Jakarta: Kementerian Pemberdayaan Perempuan dan Perlindungan Anak (KPP\&PA).

Koran Harian Kompas. edisi 20. Juni 2015. Pernikahan Dini Memicu Masalah.

Malik Kamal, Abu. 2007. Fikih Sunah Wanita. Jakarta: Pena Pundi Aksara.

Pusat Bahasa. 2011. Kamus Besar Bahasa Indonesia, cet. IV. Jakarta: PT. Gramedia Pustaka Utama.

Qardhawi, Yusuf. 2010. Halal dan Haram dalam Islam. Jld. IX. Terjemahan oleh Ahmad Semait. Jakarta: Pustaka Nasional.

Republik Indonesia. 2009. Undang-Undang Nomor 52 Tahun 2009 Tentang Perkembangan Kependudukan dan Pembangunan Keluarga. Sekretariat Negara RI. Jakarta.

Republik Indonesia. 2014. Peraturan Pemerintah Nomor 61 Tahun 2014 Tentang Kesehatan
Reproduksi. Sekretariat Negara RI. Jakarta.

Republik Indonesia. 2014. Peraturan Pemerintah Nomor 87 Tahun 2014 Tentang Perkembangan Kependudukan, Keluarga Berencana, dan Sistem Informasi Keluarga. Sekretariat Negara RI. Jakarta.

Republik Indonesia. 2014. Undang-Undang Nomor 36 Tahun 2009 Tentang Kesehatan. Sekretariat Negara RI. Jakarta.

Sarwono, Prawirihardjo. 2005. Faktor yang Mempengaruhi Perkembangan $K B$. Jakarta: Yayasan Bina Pusataka.

Sedarmayanti dan Hidayat, Syarifudin. 2002. Metodologi Penelitian. Bandung: CV Mandar Maju.

Soekanto, Soerjono dan Mamudji, Sri. 2001. Penelitian Hukum Normatif (Suatu Tinjauan Singkat). Jakarta: Rajawali Pers.

Suratun (at all). 2008. Pelayanan Keluarga Berencana dan Pelayanan Kontrasepsi. Jakarta: Trans Info Media.

Surapaty, Surya Chandra (at. all). 2016. Buku Kebijakan Program Kependudukan, Keluarga Berencana, dan Pembangunan Keluarga dalam Mendukung Keluarga Sehat. Jakarta: BKKBN.

Warson Munawir, Ahmad. 2002. Kamus Munawir Arab-Indonesia Terlengkap. Cet.II. Surabaya: Pustaka Progresif.

Wirdhana, Indra. 2013. Delapan Fungsi Keluarga. Jakarta: Direktorat Bina Ketahanan Remaja. 